\title{
Factors affecting the sensitivity of human-derived esophageal carcinoma cell lines to 5-fluorouracil and cisplatin
}

\author{
TETSUYA MINEGAKI ${ }^{1}$, KOHJI TAKARA ${ }^{2}$, RYOHEI HAMAGUCHI ${ }^{1}$, \\ MASAYUKI TSUJIMOTO $^{1}$ and KOHSHI NISHIGUCHI ${ }^{1}$ \\ ${ }^{1}$ Department of Clinical Pharmacy, Faculty of Pharmaceutical Sciences, Kyoto Pharmaceutical University, \\ Kyoto 607-8414; ${ }^{2}$ Department of Clinical Pharmaceutics, Faculty of Pharmaceutical Sciences, \\ Himeji Dokkyo University, Himeji 670-8524, Japan
}

Received August 16, 2012; Accepted October 26, 2012

DOI: $10.3892 / \mathrm{ol} .2012 .1014$

\begin{abstract}
Effective chemotherapy against esophageal carcinoma is considered achievable with a combination of 5-fluorouracil (5-FU) and cisplatin (CDDP). However, chemotherapy remains ineffective in certain patients. The aim of this study was to clarify the factors which affect sensitivity to 5-FU and CDDP. The effects of factors known to influence sensitivity to 5-FU and CDDP, namely transporters, DNA repair enzymes and metabolic enzymes, were examined. mRNA levels of four transporters, SLC22A2, SLC23A2, ABCB1 and ABCC2, two DNA repair-related enzymes, Rad51 and MSH2, and one metabolic enzyme, dihydropyrimidine dehydrogenase (DPYD), showed a strong correlation $(|r|>0.7)$ with $\mathrm{IC}_{50}$ values for 5-FU. In addition, the mRNA levels of ABCC2, MSH2 and DPYD showed a strong correlation ( $|r|>0.7)$ with the $\mathrm{IC}_{50}$ values for CDDP. Gimeracil, a DPYD inhibitor, enhanced the sensitivity of some cells to 5-FU but decreased the sensitivity of all the cells to CDDP. The inhibitory effects of ABCC2 with MK571 did not correspond to those observed in the correlation analysis. In conclusion, mRNA levels of SLC22A2, SLC23A2, ABCB1, ABCC2, Rad51, MSH2 and DPYD were confirmed to be strongly correlated with $\mathrm{IC}_{50}$ values for 5-FU, and mRNA levels of ABCC2, MSH2 and DPYD were confirmed to be strongly correlated with $\mathrm{IC}_{50}$ values for CDDP. In addition, the inhibition of DPYD appeared to affect the cytotoxicity of CDDP.
\end{abstract}

\section{Introduction}

In Japan, one-third of all mortalities are cancer-related (1). The incidence of lung, colorectal and breast cancer is

Correspondence to: Mr. Tetsuya Minegaki, Department of Clinical Pharmacy, Faculty of Pharmaceutical Sciences, Kyoto Pharmaceutical University, 5 Nakauchi-cho, Misasagi, Yamashina-ku, Kyoto 607-8414, Japan

E-mail: t-minegaki@mb.kyoto-phu.ac.jp

Key words: esophageal carcinoma, cisplatin, 5-fluorouracil, drug sensitivity increasing in Japan as well as worldwide (1). Esophageal carcinoma has a lower incidence than other types of cancer, but 5-fluorouracil (5-FU) and cisplatin (CDDP)-based chemoradiotherapy results in moderately high response and survival rates relative to other types of cancer. In fact, the complete response and 5-year survival rates following 5-FU and CDDPbased chemoradiotherapy have been reported to be 58 and $29 \%$, respectively, among Japanese esophageal carcinoma patients (2). However, chemotherapy remains ineffective in certain patients. Therefore, identifying the factors that affect sensitivity to 5-FU and CDDP is necessary for enhancing the clinical outcome of chemotherapy for esophageal carcinoma.

Certain factors affecting sensitivity to 5-FU or CDDP have previously been revealed, including the molecular mechanisms involved in the cellular kinetics and dynamics of 5-FU and CDDP. For example, overexpression of the ABC transporter superfamily C5 (ABCC5/MRP5) decreases cellular accumulation of 5-FU, resulting in resistance to 5-FU (3). In addition, dihydropyrimidine dehydrogenase (DPYD), a 5-FU metabolizing enzyme, has been correlated with clinical response to 5-FU-based chemotherapy among colon cancer patients $(4,5)$. The cytotoxic effects of CDDP are also attenuated by ERCC1, a DNA repair-related enzyme associated with restoration of DNA damage induced by chemotherapeutic agents or UV rays (6-8). However, there is little information concerning whether the levels of these molecules are predictive of sensitivity to 5-FU or CDDP in esophageal carcinoma.

In the present study, sensitivity to 5-FU and CDDP and mRNA levels of 35 genes, including drug transporters, DNA repair enzymes and metabolic enzymes, were evaluated in 5 human esophageal carcinoma cell lines. Based on these findings, factors affecting the sensitivity of esophageal carcinoma cells to 5-FU and CDDP were examined.

\section{Materials and methods}

Chemicals. 5-FU was obtained from Sigma-Aldrich Chemical Co. (St. Louis, MO, USA). CDDP was purchased from Wako Pure Chemical Industries, Ltd. (Osaka, Japan). Gimeracil and MK571 were purchased from Toronto Research Chemicals, Inc. (Toronto, ON, Canada) and Cayman Chemical Company (Ann Arbor, MI, USA), respectively. 2-(4-Iodophenyl)-5-(2,4- 
disulfophenyl)-2H-tetrazolium, monosodium salt (WST-1) and 1-methoxy-5-methylphenazinium methylsulfate were purchased from Dojindo Laboratories (Kumamoto, Japan).

Cell culture. The human esophageal adenocarcinoma cell line OE33 was purchased from DS Pharma Biomedical Co., Ltd. (Osaka, Japan) and the squamous carcinoma cell lines KYSE30, KYSE70, KYSE140 and KYSE150 (9) were obtained from Health Science Research Resources Bank (Osaka, Japan). OE33 and the other cell lines were maintained in RPMI-1640 medium (Invitrogen Corp., Carlsbad, CA, USA) and Dulbecco's modified Eagle's medium (Invitrogen), respectively, supplemented with $10 \%$ heat-inactivated fetal bovine serum (lot no. 1335770 and 348777, Invitrogen). Cells were cultured in an atmosphere of $95 \%$ air and $5 \% \mathrm{CO}_{2}$ at $37^{\circ} \mathrm{C}$ and subcultured every 3 or 4 days at a density of $1 \times 10^{6}$ cells $/ 25 \mathrm{~cm}^{2}$ culture flask. The number of passages for OE33, KYSE30, KYSE70, KYSE140 and KYSE150 cells was 15-25, 15-28, 15-26, 21-31 and 19-31, respectively.

Growth rate of esophageal carcinoma cell lines. The growth rate of esophageal carcinoma cells was evaluated with a WST-1 assay utilizing succinate dehydrogenase activity. Cells were seeded onto a 96-well plate (Corning Inc., Corning, NY, USA) at a density of $5 \times 10^{3}$ cells/well/100 $\mu 1$ and cultured in an atmosphere of $95 \%$ air and $5 \% \mathrm{CO}_{2}$ at $37^{\circ} \mathrm{C}$. After 0 , $6,12,18,24,36,48,72$ and $96 \mathrm{~h}$, the culture medium was exchanged for $110 \mu \mathrm{l}$ of medium containing WST-1 reagent solution (10 $\mu$ l WST-1 solution and $100 \mu 1$ culture medium), and $3 \mathrm{~h}$ later the absorbance was determined using a microplate reader at $450 \mathrm{~nm}$ with a reference wavelength of $620 \mathrm{~nm}$ (SpectraFluor $^{\mathrm{TM}}$, Tecan Group Ltd., Männedorf, Switzerland). The doubling time for cell growth was calculated from the logarithmic phase of a growth curve (10) as follows: Doubling time $=\left(\mathrm{t}_{1}-\mathrm{t}_{0}\right) \times \log _{10} 2 /\left(\log _{10} \mathrm{~N}_{1}-\log _{10} \mathrm{~N}_{0}\right) . \mathrm{N}_{0}$ and $\mathrm{N}_{1}$ are the number of cells (\% of day 0 ) at $t_{1}$ and $t_{0}$, respectively.

Growth inhibitory activityassay. Cells were seeded onto 96-well plates (Corning Inc.) at a density of $5 \times 10^{3}$ cells/well/100 $\mu \mathrm{l}$ on day 0 . After incubation for $24 \mathrm{~h}$, the culture medium was exchanged for one containing 5-FU or CDDP at various concentrations (day 1). On day 4, a WST-1 assay was performed as described above.

The effects of gimeracil and MK571 on the growth inhibitory effects of 5-FU and CDDP were also evaluated by WST-1 assay. Cells were incubated for $24 \mathrm{~h}$ as described above and the culture medium was exchanged for one containing 5-FU or CDDP at various concentrations with or without gimeracil $(100 \mu \mathrm{M})$ or MK571 $(50 \mu \mathrm{M})$. Following incubation for $72 \mathrm{~h}$ at $37^{\circ} \mathrm{C}$, the culture medium was replaced with a medium containing WST-1 and the absorbance was measured.

The $50 \%$ growth inhibitory concentrations $\left(\mathrm{IC}_{50}\right)$ were calculated according to the sigmoid inhibitory effect model: $\mathrm{E}=\mathrm{E}_{\max } \mathrm{x}\left[1-\mathrm{C}^{\gamma} /\left(\mathrm{C}^{\gamma}+\mathrm{IC}_{50}{ }^{\gamma}\right)\right]$, using the nonlinear least-squares fitting method (Solver, Microsoft ${ }^{\circledR}$ Excel). E and $\mathrm{E}_{\max }$ represent the surviving fraction (\% of control) and its maximum, respectively. $\mathrm{C}$ and $\gamma$ are the drug concentration in the medium and the sigmoidicity factor, respectively. Relative sensitivity was calculated as follows: Relative sensitivity $=\mathrm{IC}_{50}$ (without gimeracil or $\mathrm{MK} 571) / \mathrm{IC}_{50}$ (with gimeracil or MK571).
Real-time reverse transcription (RT)-PCR. The mRNA expression levels were measured by real-time RT-PCR. Cells were seeded at a density of $2 \times 10^{6}$ cells $/ 60 \mathrm{~mm}$ culture dish and $48 \mathrm{~h}$ later, total RNA was extracted from the cells with a GenEluteTM Mammalian Total RNA Miniprep kit (Sigma-Aldrich). Total RNA $(1 \mu \mathrm{g})$ was used for RT with a PrimeScriptTM RT reagent kit (Takara Bio, Inc., Shiga, Japan) and a thermal cycler (i-Cycler, Bio-Rad Laboratories, Inc., Hercules, CA, USA). The RT reaction was conducted in $40 \mu \mathrm{l}$ reaction buffer at $37^{\circ} \mathrm{C}$ for $15 \mathrm{~min}$ and terminated by heating at $85^{\circ} \mathrm{C}$ for $5 \mathrm{sec}$ followed by cooling at $4^{\circ} \mathrm{C}$.

Real-time PCR was performed with a 7500 Real-time PCR system (Applied Biosystems, Carlsbad, CA, USA) and SYBR Premix Ex Taq ${ }^{\mathrm{TM}}$ (Takara Bio, Inc.). The primer sequences are shown in Table I. PCR was performed at $95^{\circ} \mathrm{C}$ for $10 \mathrm{sec}$, followed by 40 cycles of $95^{\circ} \mathrm{C}$ for $5 \mathrm{sec}$ and $60^{\circ} \mathrm{C}$ for $34 \mathrm{sec}$. Dissociation was initiated at $95^{\circ} \mathrm{C}$ for $15 \mathrm{sec}$ followed by $60^{\circ} \mathrm{C}$ for $1 \mathrm{~min}$ and $95^{\circ} \mathrm{C}$ for $15 \mathrm{sec}$. To compare the relative expression of target mRNA levels between the cell lines, the comparative $\mathrm{Ct}$ method was used, as previously described (10); $\beta$-actin (ACTB) was used as an internal standard. Samples were prepared in duplicate and three independent sample sets were analyzed.

Statistical analyses. Data are shown as the mean \pm standard deviation (SD). Comparisons between 2 and among 3 or more groups were performed with Student's unpaired t-test and repeated one-way analysis of variance (ANOVA) followed by Scheffe's $\mathrm{F}$ test, respectively. $\mathrm{P}<0.05$ (two-tailed) was considered to indicate a statistically significant result. The correlation analysis was performed using Pearson's correlation coefficient (r).

\section{Results}

Growth rates of esophageal carcinoma cell lines. Table II shows the cell growth doubling times for the 5 esophageal carcinoma cell lines. Doubling times for the cells varied from 20 to $25 \mathrm{~h}$, revealing a significant difference between lines. KYSE30 cells $(20.1 \pm 1.41 \mathrm{~h})$ had the shortest doubling time and OE33 cells $(25.0 \pm 0.90 \mathrm{~h})$ the longest.

Sensitivity of esophageal carcinoma cell lines to 5-FU and $C D D P$. The $\mathrm{IC}_{50}$ values for 5-FU were markedly different among the cell lines (0.524-30.2 $\mu \mathrm{M})$; the OE33 cells showed the highest sensitivity to 5-FU and the KYSE30 cells the lowest sensitivity (Table III). In the case of CDDP, the $\mathrm{IC}_{50}$ values were also substantially different among the cell lines (2.17-19.5 $\mu \mathrm{M})$. The rank order of sensitivity to CDDP was comparable to that for 5-FU.

Correlation analysis of factors affecting drug sensitivity. The level of mRNA expression differed among the esophageal carcinoma cell lines (Table IV). The correlations between the $\mathrm{IC}_{50}$ values and the mRNA levels of the 35 different genes were analyzed (Table V). SLC22A3 mRNA was not detected in any cells, with the exception of the OE33 cell line. ABCC6 mRNA expression was not observed in KYSE30 and KYSE70 cells.

The mRNA levels of SLC22A2, SLC23A2, ABCB1 and Rad51 showed a strong negative correlation $(r<-0.7)$ with the $\mathrm{IC}_{50}$ values for 5-FU. ABCC2, MSH2 and DPYD were positively 
Table I. Sequences of oligonucleotide primers designed for real-time PCR.

\begin{tabular}{|c|c|c|c|}
\hline Function and gene & Forward (5'-3') & Reverse (5'-3') & Reference \\
\hline ACTB & TCATGAAGTGTGACGTGGACATC & TGCATCCTGTCGGCAATG & 10 \\
\hline \multicolumn{4}{|l|}{ Transport } \\
\hline SLC22A1 & TCTTCCATCGTCACTGAGTTCAAC & AGAAGCCCGCATTCAAACAG & 10 \\
\hline SLC22A2 & TCTACTCTGCCCTGGTTGAATTC & ATGCAGCCCAAGGGTAACG & 10 \\
\hline SLC22A3 & TAGCCCCATTTCTGCTCTTTC & AGATGGATGCCAGGATACCAA & 10 \\
\hline SLC23A2 & TCTTTGTGCTTGGATTTTCGAT & ACGTTCAACACTTGATCGATTC & 23 \\
\hline SLC31A1 & ACAAGTCAGCATTCGCTACAATTC & TTGCAGGAGGTGAGGAAAGC & 9 \\
\hline $\mathrm{ABCB} 1$ & TTCCTTCACCCAGGCAATG & ATGAGTTTATGTGCCACCAAGTAG & a \\
\hline $\mathrm{ABCC} 1$ & CAGTGACCTCTGGTCCTTAAACAA & TTGGCGCATTCCTTCTTCC & 24 \\
\hline $\mathrm{ABCC} 2$ & ACTTGTGACATCGGTAGCATGGA & AAGAGGCAGTTTGTGAGGGATGA & a \\
\hline $\mathrm{ABCC} 3$ & GTCCGCAGAATGGACTTGAT & TCACCACTTGGGGATCATTT & 25 \\
\hline $\mathrm{ABCC} 4$ & GCTCAGGTTGCCTATGTGCT & CGGTTACATTTCCTCCTCCA & 25 \\
\hline $\mathrm{ABCC} 5$ & CGAAGGGTTGTGTGGATCTT & GTTTCACCATGAAGGCTGGT & a \\
\hline ABCC6 & TGTCGCTCTTTGGAAAATCC & AGGAACACTGCGAAGCTCAT & 25 \\
\hline ABCG2 & TGACGGTGAGAGAAAACTTAC & TGCCACTTTATCCAGACCT & 26 \\
\hline ATP7A & AGATACTGGGACACTGGAGAAA & AGGTCATCCCTTCCACTTTCA & 10 \\
\hline ATP7B & TGATTTATAACCTGGTTGGGATACC & ATGAGAGCACCACAGACACAGA & 10 \\
\hline \multicolumn{4}{|l|}{ DNA repair } \\
\hline ERCC1 & TACAAGGCCTATGAGCAGAAACCA & TCTCTTGATGCGGCGATGAG & a \\
\hline ERCC2 & CTGGAGGTGACCAAACTCATCTA & CСTGCTTCTCATAGAAGTTGAGC & 27 \\
\hline ERCC3 & TATCCCAGGACACACAGGAAAT & TCACCTTGAAGCTATAACCTTGA & a \\
\hline XPA & TGCGGCGAGCAGTAAGAAG & TCATGGCCACACATAGTACAAGTC & a \\
\hline Rad51 & TGGGAACTGCAACTCATCTGG & GCGCTCCTCTCTCCAGCAG & 28 \\
\hline BRCA1 & ACAGCTGTGTGGTGCTTCTGTG & CATTGTCCTCTGTCCAGGCATC & 29 \\
\hline BRCA2 & TGAAGAGCAGTTAAGAGCCTTGAA & ACGGTTGTGACATCCCTTGATAAA & a \\
\hline HMGB1 & CAAGCGAACAGCAGGGTTAG & CAGATTGAGTCATTTGCTCCTCTTA & a \\
\hline HMGB2 & TGAACATCGCCCAAAGATCA & TCAGACCACATTTCACCCAATT & a \\
\hline MLH1 & GATTACCCCTTCTGATTGACA & ACTGAGGCTTTCAAAACA & 30 \\
\hline MSH2 & CAGTATATTGGAGAATCGCA & AGGGCATTTGTTTCACC & 30 \\
\hline PMS2 & AGTCAGCGTGCAGCAGTTATT & GACCATTTTGGCATACTCCTTCT & a \\
\hline RPP25 & AGAATGGTGGACAGTGGGATT & TACTTCAGGTGCTCTTCGTGAATG & a \\
\hline \multicolumn{4}{|l|}{ Metabolism } \\
\hline GSTP1 & CTGCGCATGCTGCTGGCAGATC & TTGGACTGGTACAGGGTGAGGTC & 31 \\
\hline GCLC & GGCAAGATACCTTTATGACCAGTT & TGCAGCACTCAAAGCCATAA & 32 \\
\hline GCLM & TGACTGCATTTGCTAAACAATTTGA & CGTGCGCTTGAATGTCAGG & 33 \\
\hline TYSM & GCCTCGGTGTGCCTTTCA & CCCGTGATGTGCGCAAT & 34 \\
\hline DPYD & AATGATTCGAAGAGCTTTTGAAGC & GTTCCCCGGATGATTCTGG & 35 \\
\hline UMPS & TAGTGTTTTGGAAACTGTTGAGGTT & CTTGCCTCCCTGCTCTCTGT & 36 \\
\hline MTHFR & CGGGTTAATTACCACCTTGTCAA & GCATTCGGCTGCAGTTCA & 36 \\
\hline
\end{tabular}

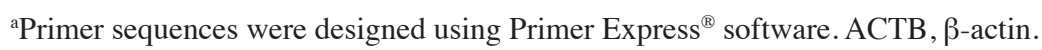

correlated with the $\mathrm{IC}_{50}$ values for 5 -FU ( $>0.7$; Table $\mathrm{V}$ and Fig. 1). In the case of CDDP, a high positive correlation coefficient ( $r>0.7$ ) was found between the $\mathrm{IC}_{50}$ values and $\mathrm{ABCC} 2$, MSH2 and DPYD mRNA expression (Table V and Fig. 2).

Effects of gimeracil and MK571 on sensitivity of esophageal carcinoma cell lines to 5-FU and CDDP. The sensitivity of KYSE30 cells to 5 -FU was enhanced by gimeracil, but in the other cell lines gimeracil had no observable effect (Table VI).
In addition, gimeracil showed a tendency to decrease the sensitivity of all the cell lines to CDDP.

MK571 had no observable effect on the KYSE30, KYSE140 and KYSE150 cells (Table VII). However, the sensitivity of KYSE70 cells to 5-FU was substantially accelerated by the presence of MK571, and the sensitivity of OE33 cells to 5-FU was markedly decreased. However, MK571 showed a tendency to decrease sensitivity to CDDP, with the exception of the KYSE30 and KYSE150 cell lines. 
Table II. Doubling times of esophageal carcinoma cell lines.

\begin{tabular}{lc}
\hline Cell line & Doubling time, mean \pm SD $(\mathrm{h})$ \\
\hline OE33 & $25.0 \pm 0.90$ \\
KYSE30 & $20.1 \pm 1.41$ \\
KYSE70 & $21.8 \pm 0.51$ \\
KYSE140 & $23.3 \pm 1.07$ \\
KYSE150 & $20.6 \pm 0.53$
\end{tabular}

$\mathrm{n}=6$.

Table III. $\mathrm{IC}_{50}$ values for 5-FU and CDDP in esophageal carcinoma cell lines.

\begin{tabular}{lcc}
\hline & \multicolumn{2}{c}{$\mathrm{IC}_{50}$ value, mean $\pm \mathrm{SD}(\mu \mathrm{M})$} \\
\cline { 2 - 3 } Cell line & $5-\mathrm{FU}$ & $\mathrm{CDDP}$ \\
\hline OE33 & $0.524 \pm 0.08$ & $2.17 \pm 0.33$ \\
KYSE30 & $30.2 \pm 8.29$ & $19.5 \pm 3.67$ \\
KYSE70 & $13.1 \pm 13.3$ & $5.27 \pm 0.36$ \\
KYSE140 & $1.88 \pm 0.38$ & $3.09 \pm 0.67$ \\
KYSE150 & $4.75 \pm 1.46$ & $14.0 \pm 1.02$ \\
\hline
\end{tabular}

n=4. 5-FU, 5-fluorouracil; CDDP, cisplatin.

\section{Discussion}

Combination chemotherapy with 5-FU and CDDP is known to be effective against esophageal carcinoma. However, it remains ineffective in certain patients, and the causes for this have not been clarified. The aim of the present study was to examine the factors affecting the sensitivity of esophageal carcinoma cells to 5-FU and CDDP.

The sensitivity of the 5 different esophageal carcinoma cell lines to 5-FU and CDDP differed (Table III). OE33, an adenocarcinoma cell line, showed a high sensitivity to 5-FU and CDDP, whereas the squamous cell carcinoma KYSE30 cells showed low sensitivity to 5-FU and CDDP. In addition, OE33 cells had the longest doubling time (an index of cell growth) of all the cell lines and KYSE30 cells the shortest (Table II), resulting in a trend for lower sensitivity to chemotherapeutic agents among cells with higher growth activity. These findings suggest that sensitivity to 5-FU and CDDP was influenced by the growth activity of cells, although cytotoxic agents such as 5-FU and CDDP are known to be more toxic in cells with higher growth activity. In order to resolve this discrepancy, further studies concerning the correlation between cell growth and sensitivity to 5-FU or CDDP should be performed.

The correlations between sensitivity to 5-FU and CDDP and the mRNA levels of the 35 genes were then examined. The levels of target mRNA expression differed among the cell lines (Table IV). The mRNA levels of ABCC2, MSH2

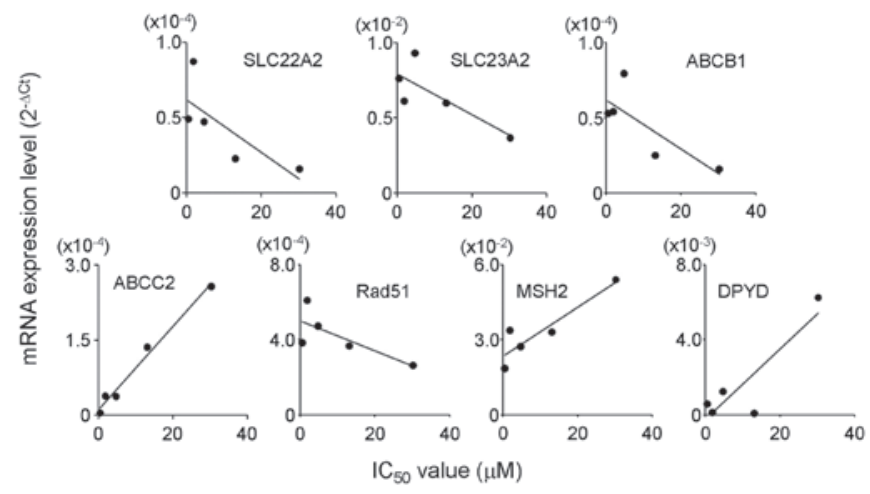

Figure 1. Correlation between $\mathrm{IC}_{50}$ values for 5-FU and mRNA expression levels in the esophageal carcinoma cell lines. $\mathrm{The}^{\mathrm{IC}_{50}}$ values for 5 -FU were obtained from growth inhibition studies (Table III). The mRNA expression levels $\left(2^{-\Delta \mathrm{Ct}}\right)$ in the cells were evaluated by real-time RT-PCR assay using $\mathrm{SYBR}^{\circledR}$-Green. The threshold cycle $(\mathrm{Ct})$ values were used to quantify the PCR product, and the relative expression level of the target gene was expressed as $2^{-\Delta \mathrm{Ct}}$. The $\Delta \mathrm{Ct}$ was calculated by subtracting $\mathrm{Ct}$ ( $\beta$-actin; as an internal standard) from $\mathrm{Ct}$ (target gene). 5-FU, 5-fluorouracil; RT, reverse transcription.

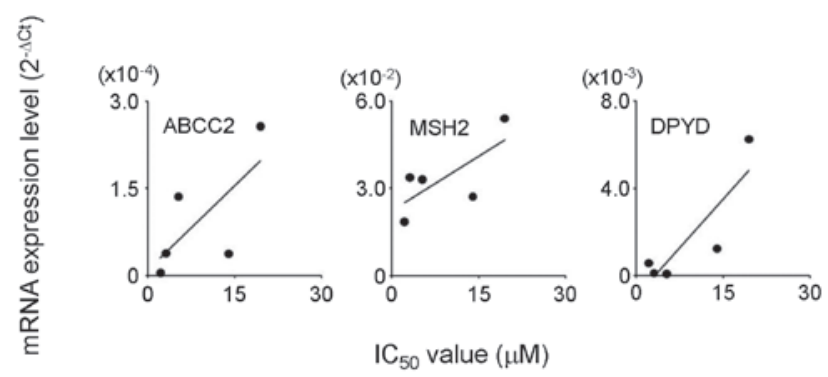

Figure 2. Correlation between the $\mathrm{IC}_{50}$ values for CDDP and mRNA expression levels in the esophageal carcinoma cell lines. The $\mathrm{IC}_{50}$ values for CDDP were obtained from growth inhibition studies (Table III). The mRNA expression levels $\left(2^{-\Delta \mathrm{Ct}}\right)$ in the cells were evaluated by real-time RT-PCR assay using $\mathrm{SYBR}^{\circledR}$-Green. The threshold cycle $(\mathrm{Ct})$ values were used to quantify the PCR product, and the relative expression level of the target gene was expressed as $2^{-\Delta C t} . \Delta C t$ was calculated by subtracting $\mathrm{Ct}$ ( $\beta$-actin; as an internal standard) from $\mathrm{Ct}$ (target gene). CDDP, cisplatin; RT, reverse transcription.

and DPYD were positively correlated with the $\mathrm{IC}_{50}$ values of 5-FU (r>0.7; Fig. 1 and Table V). By contrast, a negative correlation between the $\mathrm{IC}_{50}$ values of 5-FU and the mRNA levels of SLC22A2, SLC23A2, ABCB1 and Rad51 was observed. In the light of the biological roles of these genes, the negative correlation between SLC22A2 and SLC23A2 mRNA expression and sensitivity was considered to be noteworthy. SLC22A2 encodes an organic cation transporter which is responsible for cell uptake of various drugs, including CDDP $(11,12)$. A colon carcinoma cell line exhibiting resistance to 5-FU has been reported to show lower expression of SLC23A2 mRNA than its parent cells (13). ABCC2, MSH2 and DPYD are known to act in detoxifying mechanisms; they are an efflux transporter, DNA repairrelated protein and metabolic enzyme, respectively. Although $\mathrm{ABCB} 1$ is a known efflux transporter that contributes to drug resistance, the cytotoxicity of 5-FU was not influenced by the expression of ABCB1 (14). In addition, the overexpres- 
Table IV. Expression levels of mRNA in esophageal carcinoma cell lines.

\begin{tabular}{|c|c|c|c|c|c|}
\hline \multirow[b]{2}{*}{ Function and gene } & \multicolumn{5}{|c|}{ Expression ratio, mean $\pm \mathrm{SD}\left(2^{-\Delta \mathrm{Ct}} \times 10^{-4}\right)$} \\
\hline & OE33 & KYSE30 & KYSE70 & KYSE140 & KYSE150 \\
\hline \multicolumn{6}{|l|}{ Transport } \\
\hline SLC22A1 & $0.11 \pm 0.03$ & $0.07 \pm 0.02$ & $0.01 \pm 0.003$ & $0.03 \pm 0.02$ & $0.12 \pm 0.07$ \\
\hline SLC22A2 & $0.49 \pm 0.15$ & $0.16 \pm 0.03$ & $0.23 \pm 0.03$ & $0.87 \pm 0.45$ & $0.47 \pm 0.36$ \\
\hline SLC22A3 & $36.3 \pm 9.24$ & ND & ND & ND & ND \\
\hline SLC23A2 & $76.1 \pm 13.8$ & $36.6 \pm 6.39$ & $59.8 \pm 4.66$ & $61.1 \pm 43.8$ & $92.9 \pm 64.0$ \\
\hline SLC31A1 & $125 \pm 26.6$ & $131 \pm 10.2$ & $179 \pm 23.4$ & $252 \pm 135$ & $244 \pm 147$ \\
\hline ABCB1 & $0.53 \pm 0.14$ & $0.16 \pm 0.03$ & $0.25 \pm 0.06$ & $0.54 \pm 0.20$ & $0.79 \pm 0.59$ \\
\hline ABCC1 & $74.7 \pm 11.3$ & $37.0 \pm 3.83$ & $246 \pm 32.9$ & $123 \pm 75.6$ & $67.8 \pm 36.6$ \\
\hline ABCC2 & $0.05 \pm 0.01$ & $2.57 \pm 0.89$ & $1.36 \pm 0.07$ & $0.38 \pm 0.16$ & $0.38 \pm 0.23$ \\
\hline ABCC3 & $80.5 \pm 15.1$ & $10.2 \pm 2.64$ & $60.7 \pm 8.62$ & $40.6 \pm 23.3$ & $123 \pm 86.7$ \\
\hline ABCC4 & $26.1 \pm 2.17$ & $28.9 \pm 1.95$ & $52.1 \pm 5.53$ & $189 \pm 105$ & $92.5 \pm 51.3$ \\
\hline ABCC5 & $9.06 \pm 1.30$ & $62.14 \pm 17.0$ & $65.38 \pm 8.60$ & $22.92 \pm 10.6$ & $26.76 \pm 19.2$ \\
\hline ABCC6 & $1.79 \pm 0.12$ & ND & ND & $0.05 \pm 0.05$ & $0.04 \pm 0.04$ \\
\hline ABCG2 & $6.25 \pm 1.29$ & $4.64 \pm 0.21$ & $1.66 \pm 0.34$ & $2.47 \pm 0.69$ & $33.1 \pm 18.3$ \\
\hline ATP7A & $8.66 \pm 1.27$ & $7.99 \pm 0.70$ & $4.68 \pm 1.20$ & $6.09 \pm 3.61$ & $15.4 \pm 7.98$ \\
\hline ATP7B & $1.91 \pm 0.25$ & $1.89 \pm 0.73$ & $2.21 \pm 0.47$ & $5.72 \pm 4.77$ & $3.37 \pm 2.69$ \\
\hline \multicolumn{6}{|l|}{ DNA repair } \\
\hline ERCC1 & $219 \pm 66.1$ & $143 \pm 35.8$ & $96.3 \pm 13.2$ & $241 \pm 131$ & $296 \pm 175$ \\
\hline ERCC2 & $43.9 \pm 4.57$ & $35.1 \pm 8.01$ & $21.0 \pm 2.52$ & $47.9 \pm 22.4$ & $52.2 \pm 22.6$ \\
\hline ERCC3 & $82.3 \pm 11.5$ & $79.3 \pm 19.4$ & $57.4 \pm 6.31$ & $134 \pm 97.9$ & $185 \pm 104$ \\
\hline XPA & $91.4 \pm 16.0$ & $107 \pm 16.7$ & $193 \pm 14.8$ & $461 \pm 290$ & $283 \pm 164$ \\
\hline $\operatorname{Rad} 51$ & $3.84 \pm 1.03$ & $2.64 \pm 0.37$ & $3.67 \pm 1.09$ & $6.09 \pm 3.07$ & $4.72 \pm 1.75$ \\
\hline BRCA1 & $90.5 \pm 15.6$ & $61.1 \pm 2.46$ & $65.3 \pm 4.56$ & $188 \pm 116$ & $151 \pm 78.8$ \\
\hline BRCA2 & $110 \pm 20.4$ & $111 \pm 3.99$ & $43.5 \pm 3.74$ & $261 \pm 165$ & $204 \pm 108$ \\
\hline HMGB1 & $35.2 \pm 7.29$ & $35.9 \pm 1.84$ & $51.4 \pm 3.98$ & $79.9 \pm 47.8$ & $37.6 \pm 19.1$ \\
\hline HMGB2 & $509 \pm 87.3$ & $1340 \pm 150$ & $1343 \pm 129$ & $1980 \pm 947$ & $1367 \pm 679$ \\
\hline MLH1 & $27.5 \pm 4.55$ & $21.3 \pm 1.61$ & $23.9 \pm 1.83$ & $28.2 \pm 18.4$ & $70.9 \pm 36.8$ \\
\hline MSH2 & $185 \pm 39.8$ & $540 \pm 38.6$ & $331 \pm 23.5$ & $338 \pm 154$ & $272 \pm 114$ \\
\hline PMS2 & $25.3 \pm 3.22$ & $34.2 \pm 4.24$ & $77.1 \pm 12.8$ & $123 \pm 81.6$ & $67.0 \pm 42.8$ \\
\hline RPP25 & $27.5 \pm 4.35$ & $6.32 \pm 0.99$ & $0.13 \pm 0.03$ & $74.9 \pm 59.9$ & $0.74 \pm 0.47$ \\
\hline \multicolumn{6}{|l|}{ Metabolism } \\
\hline GSTP1 & $2444 \pm 425$ & $2926 \pm 644$ & $3421 \pm 380$ & $5784 \pm 3549$ & $7249 \pm 3978$ \\
\hline GCLC & $5.21 \pm 0.51$ & $3.87 \pm 1.15$ & $45.0 \pm 4.30$ & $10.8 \pm 4.41$ & $9.05 \pm 5.39$ \\
\hline GCLM & $8.38 \pm 2.61$ & $31.34 \pm 4.30$ & $75.1 \pm 10.8$ & $33.0 \pm 15.4$ & $32.1 \pm 22.2$ \\
\hline TYMS & $54.0 \pm 11.6$ & $163 \pm 3.10$ & $2511 \pm 136$ & $81.8 \pm 32.9$ & $215.6 \pm 102$ \\
\hline DPYD & $5.81 \pm 2.03$ & $62.4 \pm 6.50$ & $0.82 \pm 0.29$ & $1.23 \pm 0.87$ & $12.4 \pm 9.82$ \\
\hline UMPS & $85.6 \pm 17.4$ & $69.0 \pm 3.85$ & $162 \pm 20.6$ & $183 \pm 108$ & $165 \pm 73.2$ \\
\hline MTHFR & $5.78 \pm 1.85$ & $10.0 \pm 2.39$ & $18.6 \pm 2.72$ & $25.6 \pm 23.2$ & $23.7 \pm 15.3$ \\
\hline
\end{tabular}

$\Delta \mathrm{Ct}=\mathrm{Ct}($ target gene $)-\mathrm{Ct}(\beta$-actin $) . \mathrm{ND}$, not detected; $\mathrm{n}=3$.

sion of DNA-repair related proteins, including Rad51, has been reported to contribute to resistance to DNA damaging agents (15). Although the present findings showing a negative correlation between $\mathrm{IC}_{50}$ values and $\mathrm{ABCB} 1$ and $\mathrm{Rad} 51$ mRNA expression levels conflict with previous findings, they may indicate that $\mathrm{ABCB} 1$ and $\operatorname{Rad} 51$ have no significant impact on sensitivity.
In the case of CDDP, a positive correlation $(r>0.7)$ between the $\mathrm{IC}_{50}$ values and the mRNA levels of $\mathrm{ABCC} 2, \mathrm{MSH} 2$ and DPYD was identified. The findings for ABCC2 and $\mathrm{MSH} 2$ are supported by their functions; the export of CDDP from cells (16) and repair of DNA damaged by CDDP (17), respectively (Table $\mathrm{V}$ and Fig. 2). In addition, proliferating cell nuclear antigen-normalized mRNA expression of DPYD 
Table V. Pearson's correlation coefficient between $\mathrm{IC}_{50}$ values for 5-FU or CDDP and mRNA expression level.

\begin{tabular}{|c|c|c|}
\hline \multirow[b]{2}{*}{ Function and gene } & \multicolumn{2}{|c|}{$\begin{array}{l}\text { Pearson's correlation } \\
\text { coefficient }(\mathrm{r})\end{array}$} \\
\hline & $5-\mathrm{FU}$ & CDDP \\
\hline \multicolumn{3}{|l|}{ Transport } \\
\hline SLC22A1 & -0.189 & 0.333 \\
\hline SLC22A2 & -0.764 & -0.574 \\
\hline SLC22A3 & ND & ND \\
\hline SLC23A2 & -0.790 & -0.302 \\
\hline SLC31A1 & -0.477 & -0.132 \\
\hline ABCB1 & -0.788 & -0.215 \\
\hline $\mathrm{ABCC} 1$ & -0.150 & -0.530 \\
\hline $\mathrm{ABCC} 2$ & $0.992^{\mathrm{b}}$ & 0.706 \\
\hline $\mathrm{ABCC} 3$ & -0.659 & -0.179 \\
\hline $\mathrm{ABCC} 4$ & -0.470 & -0.315 \\
\hline ABCC5 & 0.573 & 0.234 \\
\hline ABCC6 & ND & ND \\
\hline ABCG2 & -0.244 & 0.398 \\
\hline ATP7A & -0.199 & 0.451 \\
\hline ATP7B & -0.485 & -0.314 \\
\hline \multicolumn{3}{|l|}{ DNA repair } \\
\hline ERCC1 & -0.638 & -0.041 \\
\hline ERCC2 & -0.533 & 0.019 \\
\hline ERCC3 & -0.439 & 0.187 \\
\hline XPA & -0.463 & -0.284 \\
\hline Rad51 & -0.756 & -0.523 \\
\hline BRCA1 & -0.653 & -0.274 \\
\hline BRCA2 & -0.455 & -0.049 \\
\hline HMGB1 & -0.341 & -0.507 \\
\hline HMGB2 & 0.010 & 0.125 \\
\hline MLH1 & -0.369 & 0.269 \\
\hline MSH2 & $0.913^{\mathrm{a}}$ & 0.719 \\
\hline PMS2 & -0.363 & -0.365 \\
\hline RPP25 & -0.486 & -0.561 \\
\hline \multicolumn{3}{|l|}{ Metabolism } \\
\hline GSTP1 & -0.401 & 0.121 \\
\hline GCLC & 0.032 & -0.321 \\
\hline GCLM & 0.287 & -0.011 \\
\hline TYMS & 0.163 & -0.211 \\
\hline DPYD & 0.881 & 0.863 \\
\hline UMPS & -0.522 & -0.379 \\
\hline MTHFR & -0.319 & -0.074 \\
\hline
\end{tabular}

$\mathrm{ND}$, not detected. ${ }^{\mathrm{a}} \mathrm{P}<0.05$ and ${ }^{\mathrm{b}} \mathrm{P}<0.01$ significant correlations between $\mathrm{IC}_{50}$ values and mRNA expression levels. 5-FU, 5-fluorouracil; CDDP, cisplatin.

has previously been reported to be associated with sensitivity to CDDP in lung cancer tissues (18). Although the correlation between CDDP and DPYD has not been investigated in detail, these previous results may support the present findings.
Table VI. Relative sensitivity of the esophageal carcinoma cell lines to 5-FU or CDDP with or without gimeracil.

\begin{tabular}{lcc}
\hline & \multicolumn{2}{c}{ Relative sensitivity, mean \pm SD (fold) } \\
\cline { 2 - 3 } Cell line & $5-\mathrm{FU}$ & $\mathrm{CDDP}$ \\
\hline OE33 & $1.10 \pm 0.37$ & $0.579 \pm 0.06$ \\
KYSE30 & $2.30 \pm 0.13$ & $0.710 \pm 0.03$ \\
KYSE70 & $1.16 \pm 0.19$ & $0.687 \pm 0.05$ \\
KYSE140 & $0.989 \pm 0.15$ & $0.691 \pm 0.10$ \\
KYSE150 & $1.19 \pm 0.16$ & $0.788 \pm 0.25$ \\
\hline Relative sensitivity, the ratio of $\mathrm{IC}_{50}$ value for 5-FU or CDDP without \\
gimeracil to those with gimeracil (n=4). Gimeracil, $100 \mu \mathrm{M}$. 5-FU, \\
5-fluorouracil; CDDP, cisplatin.
\end{tabular}

Table VII. Relative sensitivity of the esophageal carcinoma cell lines to 5-FU or CDDP with or without MK571.

\begin{tabular}{lrr}
\hline & \multicolumn{2}{c}{ Relative sensitivity, mean \pm SD (fold) } \\
\cline { 2 - 3 } Cell line & \multicolumn{1}{c}{5 -FU } & \multicolumn{1}{c}{ CDDP } \\
\hline OE33 & $0.0680 \pm 0.01$ & $0.852 \pm 0.28$ \\
KYSE30 & $0.961 \pm 0.06$ & $0.974 \pm 0.09$ \\
KYSE70 & $2.36 \pm 1.36$ & $0.617 \pm 0.06$ \\
KYSE140 & $0.813 \pm 0.16$ & $0.803 \pm 0.04$ \\
KYSE150 & $0.731 \pm 0.11$ & $1.08 \pm 0.26$
\end{tabular}

Relative sensitivity, the ratio of $\mathrm{IC}_{50}$ values for 5-FU or CDDP without MK571 to those with MK571 (n=4). MK571, $50 \mu$ M. 5-FU, 5-fluorouracil; CDDP, cisplatin.

The mRNA levels of ABCC2, MSH2 and DPYD correlated well with sensitivity to both 5-FU and CDDP, suggesting that these are potent predictive factors for 5-FU and CDDP-based chemotherapy in esophageal carcinoma patients.

Finally, the roles of ABCC2 and DPYD in sensitivity to 5-FU and CDDP were examined, since the knock-down of MSH2 in SW460 and HeLa cells has been reported to have no influence on sensitivity to 5-FU (19). In the present study, $100 \mu \mathrm{M}$ gimeracil, which showed sufficient inhibition of DPYD (20), enhanced 5-FU sensitivity in the KYSE30 cell line (Table VI), which had the highest level of DPYD mRNA expression of all the cell lines tested (Table IV). The present findings support those of Ando et al (21); that is, DPYD was a predictor of sensitivity to 5-FU. Apart from the correlation analysis, gimeracil decreased sensitivity to CDDP in all cell lines (Table VI), implying that DPYD activity may be required for the cytotoxic effect of CDDP. Further investigations are required to resolve this contradiction. The concomitant administration of $50 \mu \mathrm{M}$ MK571, a representative $\mathrm{ABCC} 2$ inhibitor (22), was found to decrease the sensitivity of OE33 and KYSE150 cells to 5-FU. In addition, the growth inhibitory activity of CDDP was decreased 
in KYSE30 and KYSE150 cell lines (Table VII). These findings conflict with the function of ABCC2 function as an efflux transporter, and further investigations are required to clarify this situation.

In conclusion, the mRNA levels of SLC22A2, SLC23A2, $\mathrm{ABCB} 1, \mathrm{ABCC} 2, \mathrm{Rad} 51, \mathrm{MSH} 2$ and DPYD were confirmed to be strongly correlated with the $\mathrm{IC}_{50}$ values for $5-\mathrm{FU}$, and those of ABCC2, MSH2 and DPYD were also confirmed to be strongly correlated with the $\mathrm{IC}_{50}$ values for CDDP. These genes have the potential to affect the sensitivity to 5-FU and CDDP. In addition, the inhibition of DPYD was suggested to affect the cytotoxicity of CDDP. These findings provide useful information for improving the clinical outcome of chemotherapy against esophageal carcinoma.

\section{Acknowledgements}

This study was supported in part by a grant of Strategic Research Foundation Grant-aided Project for Private Universities from the Ministry of Education, Culture, Sport, Science and Technology, Japan.

\section{References}

1. National Cancer Center: Cancer statistics in Japan 2011. http:// ganjoho.jp/public/statistics/backnumber/2011_jp.html. Accessed June 29, 2012.

2. Tahara M, Ohtsu A, Hironaka S, Boku N, Ishikura S, Miyata Y, Ogino $\mathrm{T}$ and Yoshida S: Clinical impact of criteria for complete response (CR) of primary site to treatment of esophageal cancer. Jpn J Clin Oncol 35: 316-323, 2005.

3. Pratt S, Shepard RL, Kandasamy RA, Johnston PA, Perry W III and Dantzig AH: The multidrug resistance protein 5 (ABCC5) confers resistance to 5-fluorouracil and transports its monophosphorylated metabolites. Mol Cancer Ther 4: 855-863, 2005.

4. Kornmann M, Schwabe W, Sander S, Kron M, Sträter J, Polat S, Kettner E, Weiser HF, Baumann W, Schramm H, Häusler P, Ott K, Behnke D, Staib L, Beger HG and Link KH: Thymidylate synthase and dihydropyrimidine dehydrogenase mRNA expression levels: predictors for survival in colorectal cancer patients receiving adjuvant 5 -fluorouracil. Clin Cancer Res 9: 4116-4124, 2003

5. Ciaparrone M, Quirino M, Schinzari G, Zannoni G, Corsi DC, Vecchio FM, Cassano A, La Torre G and Barone C: Predictive role of thymidylate synthase, dihydropyrimidine dehydrogenase and thymidine phosphorylase expression in colorectal cancer patients receiving adjuvant 5-fluorouracil. Oncology 70: 366-377, 2006.

6. Larminat F and Bohr VA: Role of the human ERCC-1 gene in gene-specific repair of cisplatin-induced DNA damage. Nucleic Acids Res 22: 3005-3010, 1994.

7. Andersson BS, Sadeghi T, Siciliano MJ, Legerski R and Murray D: Nucleotide excision repair genes as determinants of cellular sensitivity to cyclophosphamide analogs. Cancer Chemother Pharmacol 38: 406-416, 1996.

8. Hsu DS, Lan HY, Huang CH, Tai SK, Chang SY, Tsai TL, Chang CC, Tzeng CH, Wu KJ, Kao JY and Yang MH: Regulation of excision repair cross-complementation group 1 by Snail contributes to cisplatin resistance in head and neck cancer. Clin Cancer Res 16: 4561-4571, 2010.

9. Shimada Y, Imamura M, Wagata T, Yamaguchi N and Tobe T: Characterization of 21 newly established esophageal cancer cell lines. Cancer 69: 277-284, 1992.

10. Kitada N, Takara K, Minegaki T, Itoh C, Tsujimoto M, Sakaeda T and Yokoyama T: Factors affecting sensitivity to antitumor platinum derivatives of human colorectal tumor cell lines. Cancer Chemother Pharmacol 62: 577-584, 2008.

11. Kimura N, Masuda S, Tanihara Y, Ueo H, Okuda M, Katsura T and Inui K: Metformin is a superior substrate for renal organic cation transporter OCT2 rather than hepatic OCT1. Drug Metab Pharmacokinet 20: 379-386, 2005.
12. Filipski KK, Loos WJ, Verweij J and Sparreboom A: Interaction of Cisplatin with the human organic cation transporter 2. Clin Cancer Res 14: 3875-3880, 2008.

13. Karasawa H, Miura K, Fujibuchi W, Ishida K, Kaneko N, Kinouchi M, Okabe M, Ando T, Murata Y, Sasaki H, Takami K, Yamamura A, Shibata C and Sasaki I: Down-regulation of cIAP2 enhances 5-FU sensitivity through the apoptotic pathway in human colon cancer cells. Cancer Sci 100: 903-913, 2009.

14. Takara K, Obata Y, Yoshikawa E, Kitada N, Sakaeda T, Ohnishi N and Yokoyama T: Molecular changes to HeLa cells on continuous exposure to cisplatin or paclitaxel. Cancer Chemother Pharmacol 58: 785-793, 2006.

15. Takenaka T, Yoshino I, Kouso H, Ohba T, Yohena T, Osoegawa A, Shoji F and Maehara Y: Combined evaluation of Rad51 and ERCC1 expressions for sensitivity to platinum agents in non-small cell lung cancer. Int J Cancer 121: 895-900, 2007.

16. Noma B, Sasaki T, Fujimoto Y, Serikawa M, Kobayashi K, Inoue $\mathrm{M}$, Itsuki $\mathrm{H}$, Kamigaki $\mathrm{M}$, Minami $\mathrm{T}$ and Chayama $\mathrm{K}$ : Expression of multidrug resistance-associated protein 2 is involved in chemotherapy resistance in human pancreatic cancer. Int J Oncol 33: 1187-1194, 2008.

17. Lan L, Hayashi T, Rabeya RM, Nakajima S, Kanno S, Takao M, Matsunaga T, Yoshino M, Ichikawa M, Riele H, Tsuchiya S, Tanaka $\mathrm{K}$ and Yasui A: Functional and physical interactions between ERCC1 and MSH2 complexes for resistance to cisdiamminedichloroplatinum(II) in mammalian cells. DNA Repair (Amst) 3: 135-143, 2004.

18. Takizawa M, Kawakami K, Obata T, Matsumoto I, Ohta Y, Oda M, Sasaki T and Watanabe G: In vitro sensitivity to platinum-derived drugs is associated with expression of thymidylate synthase and dihydropyrimidine dehydrogenase in human lung cancer. Oncol Rep 15: 1533-1539, 2006.

19. Pettersen HS, Visnes T, Vågb $\varnothing \mathrm{CB}$, Svaasand EK, Doseth B, Slupphaug G, Kavli B and Krokan HE: UNG-initiated base excision repair is the major repair route for 5-fluorouracil in DNA, but 5-fluorouracil cytotoxicity depends mainly on RNA incorporation. Nucleic Acids Res 39: 8430-8444, 2011.

20. Li Y, Mizutani Y, Shiraishi T, Nakamura T, Mikami K, Takaha N, Okihara K, Kawauchi A, Sakai T and Miki T: The significance of the expression of dihydropyrimidine dehydrogenase in prostate cancer. BJU Int 99: 663-668, 2007.

21. Ando T, Ishiguro H, Kuwabara Y, Kimura M, Mitsui A, Sugito N, Mori R, Ogawa R, Katada T and Fujii Y: Relationship between expression of 5-fluorouracil metabolic enzymes and 5-fluorouracil sensitivity in esophageal carcinoma cell lines. Dis Esophagus 21: 15-20, 2008.

22. Pedersen JM, Matsson P, Bergström CA, Norinder U, Hoogstraate $\mathrm{J}$ and Artursson P: Prediction and identification of drug interactions with the human ATP-binding cassette transporter multidrug-resistance associated protein 2 (MRP2; ABCC2). J Med Chem 51: 3275-3287, 2008.

23. Reidling JC, Subramanian VS, Dahhan T, Sadat M and Said HM: Mechanisms and regulation of vitamin C uptake: studies of the hSVCT systems in human liver epithelial cells. Am J Physiol Gastrointest Liver Physiol 295: 1217-1227, 2008.

24. Nishimura M, Koeda A, Morikawa H, Satoh T, Narimatsu S and Naito S: Comparison of inducibility of multidrug resistance (MDR)1, multidrug resistance-associated protein (MRP)1, and MRP2 mRNAs by prototypical microsomal enzyme inducers in primary cultures of human and cynomolgus monkey hepatocytes. Biol Pharm Bull 31: 2068-2072, 2008.

25. Maubon N, Le Vee M, Fossati L, Audry M, Le Ferrec E, Bolze S and Fardel O: Analysis of drug transporter expression in human intestinal Caco-2 cells by real-time PCR. Fundam Clin Pharmacol 21: 659-663, 2007.

26. Dauchy S, Miller F, Couraud PO, Weaver RJ, Weksler B, Romero IA, Scherrmann JM, De Waziers I and Declèves X: Expression and transcriptional regulation of $\mathrm{ABC}$ transporters and cytochromes P450 in hCMEC/D3 human cerebral microvascular endothelial cells. Biochem Pharmacol 77: 897-909, 2009.

27. Shimizu J, Horio Y, Osada H, Hida T, Hasegawa Y, Shimokata K, Takahashi T, Sekido Y and Yatabe Y: mRNA expression of RRM1, ERCC1 and ERCC2 is not associated with chemosensitivity to cisplatin, carboplatin and gemcitabine in human lung cancer cell lines. Respirology 13: 510-517, 2008.

28. Sliwinski T, Krupa R, Majsterek I, Rykala J, Kolacinska A, Morawiec Z, Drzewoski J, Zadrozny M and Blasiak J: Polymorphisms of the BRCA2 and RAD51 genes in breast cancer. Breast Cancer Res Treat 94: 105-109, 2005. 
29. Amirrad M, Al-Mulla F, Varadharaj G, John B, Saji T and Anim JT: BRCA1 gene expression in breast cancer in Kuwait: correlation with prognostic parameters. Med Princ Pract 14 67-72, 2005.

30. Müller A, Zielinski D, Friedrichs N, Oberschmid B, Merkelbach-Bruse S, Schackert HK, Linnebacher M, von Knebel Doeberitz M, Büttner R and Rüschoff J: Reduced mRNA expression in paraffin-embedded tissue identifies MLH1and MSH2-deficient colorectal tumours and potential mutation carriers. Virchows Arch 453: 9-16, 2008.

31. Veeriah S, Kautenburger T, Habermann N, Sauer J, Dietrich H, Will F and Pool-Zobel BL: Apple flavonoids inhibit growth of HT29 human colon cancer cells and modulate expression of genes involved in the biotransformation of xenobiotics. Mol Carcinog 45: 164-174, 2006.

32. Uthus EO, Reeves PG and Saari JT: Copper deficiency decreases plasma homocysteine in rats. J Nutr 137: 1370-1374, 2007.

33. Hoang YD, Avakian AP and Luderer U: Minimal ovarian upregulation of glutamate cysteine ligase expression in response to suppression of glutathione by buthionine sulfoximine. Reprod Toxicol 21: 186-196, 2006.
34. Gustavsson B, Kaiser C, Carlsson G, Wettergren Y, Odin E, Lindskog EB, Niyikiza C and Ma D: Molecular determinants of efficacy for 5-FU-based treatments in advanced colorectal cancer: mRNA expression for 18 chemotherapy-related genes. Int J Cancer 124: 1220-1226, 2009.

35. Yoshinare K, Kubota T, Watanabe M, Wada N, Nishibori H, Hasegawa H, Kitajima M, Takechi T and Fukushima M: Gene expression in colorectal cancer and in vitro chemosensitivity to 5-fluorouracil: a study of 88 surgical specimens. Cancer Sci 94: 633-638, 2003

36. Matsubara J, Nishina T, Yamada Y, Moriwaki T, Shimoda T, Kajiwara T, Nakajima TE, Kato K, Hamaguchi T, Shimada Y, Okayama Y, Oka T and Shirao K: Impacts of excision repair cross-complementing gene 1 (ERCC1), dihydropyrimidine dehydrogenase, and epidermal growth factor receptor on the outcomes of patients with advanced gastric cancer. Br J Cancer 98: 832-839, 2008. 